DOI: $\underline{10.35619 / \text { iiu.v1i10.180 }}$

Юрчук Олексій

кандидат педагогічних наук, старший викладач кафедри педагогіки і психології (дошкільної та корекційної) імені проф. Т. І. Поніманської Рівненського державного гуманітарного університету

м. Рівне, Україна

ORCID: 0000-0002-4764-1783

e-mail: abstractio@ukr.net

\title{
ОСНОВНІ ПІДХОДИ ДО ПРОЦЕСУ ПІДГОТОВКИ МАЙБУТНІХ ВИХОВАТЕЛІВ ДО ЗДІЙСНЕННЯ РУХОВОГО РЕЖИМУ В ЗАКЛАДАХ ДОШКІЛЬНОЇ ОСВІТИ
}

\begin{abstract}
Анотація. У статті розглядаються особливості процесу підготовки майбутніх вихователів до здійснення рухового режиму в закладах дошкільної освіти. Проаналізовано погляди вітчизняних та зарубіжних науковців на різні теоретичні педагогічні підходи: системний, компетентнісний та діяльнісний. Розкрито значимість сучасних методологічних підходів як вирішальних для наукового обгрунтування ефективної професійної підготовки та формування професійних знань майбутніх вихователів щодо здійснення рухового режиму в ЗДО. Обгрунтовані методологічні підходи та розкриті їх можливості в організації процесу підготовки майбутніх вихователів до здійснення рухового режиму в ЗДО.

3'ясовано, що використання системного підходу уможливлює забезпечення цілісності процесу формування професійної компетентності майбутніх вихователів за допомогою діяльності самого викладача, суб'єктивної свободи у виборі діяльності та їі компонентів, проаналізувати місця та функції усіх ii складників i побудову iii теоретичної моделі.

У межах компетентнісного підходу простежено статус компетенцій як результату освіти, що охоплює всі аспекти діяльності - знаннєву, операційно-технологічну, ціннісно-мотиваційну тощо.
\end{abstract}

Визначено ефективність діяльнісного підходу до процесу професійного становлення майбутніх вихователів у наближених до професійних умов. Звернено увагу, що організація пізнавальної діяльності базована на такому підході дає підстави для перегляду традиційних уявлень про освітній процес, забезпечуючи перетворення майбутніх вихователів із об'єкта впливу з боку викладача, в активний суб'єкт освітньої діяльності.

Ключові слова: майбутні вихователі, руховий режим, теоретичні підходи, системний підхід, компетентнісний підхід, діяльнісний підхід.

Постановка проблеми. Регламентація в Законі України «Про дошкільну освіту» періоду дошкілля як базового етапу фізичного, психологічного та соціального становлення дитячої особистості, увиразнює пріоритетність фізичного виховання саме в цьому віці. У такому контексті важливо, що основою системи фізичного виховання дітей дошкільного віку є руховий режим, негативна динаміка змін якого призводить до загострення уваги до нього педагогічних працівників дошкільних навчальних закладів і батьків. Саме тому особливого значення набуває перегляд пріоритетів у системі професійної підготовки майбутнього вихователя, а також створення умов для всебічного розвитку їхніх інтелектуальних і професійних якостей. Тому важливим завданням постає підготовка майбутніх вихователів до здійснення рухового режиму в закладах дошкільної освіти (ЗДО). Для належного осмислення сутності підготовки 
майбутніх вихователів до здійснення рухового режиму в ЗДО видається доцільним проаналізувати використані в дослідженні методологічні підходи.

Аналіз останніх досліджень 3 проблеми. Для вдосконалення професійної підготовки майбутніх вихователів вітчизняні та зарубіжні науковці пропонують різні теоретичні педагогічні підходи: системний (I. В. Блауберг, В. П. Кузьмін, В. М. Садовський, Е. Г. Юдін, О. А. Дубасенюк, С. О. Сисоєва, Л. П. Сущенко та ін), компетентнісний (О. Л. Богініч, А. М. Богуш, Н.В. Гавриш, О. І. Гура, О. А. Дубасенюк, А. П. Конох, Т.М. Котик, С. А. Литвиненко, С. В. Лісова, О. В. Овчарук, О. І. Пометун, Т. І. Поніманська, В. А. Семиченко), діяльнісний (Л. Г. Семушина, Н. Є. Колесник, Т. П. Танько, Ю. Г. Татур та ін.).

На етапі забезпечення нового рівня освіти вважаємо за необхідне виокремити сучасні підходи, що сприятимуть підвищенню ефективності фахової підготовки майбутніх вихователів до здійснення рухового режиму в закладах дошкільної освіти.

Метою дослідження є 3'ясування сутності сучасних методологічних підходів до підготовки майбутніх вихователів до здійснення рухового режиму в закладах дошкільної освіти.

Виклад основного матеріалу дослідження. У фаховій літературі 3 питань методології поняття «підхід» тлумачать по-різному. 3 одного боку, науковці розглядають його як певний засадничий принцип, засадничу позицію, основне положення чи переконання (цілісний, комплексний, системний, синергетичний тощо), 3 іншого - як напрям вивчення предмета дослідження (історичний, логічний, змістовий, формальний та ін.). На погляд філософа М. С. Кагана (1991, с. 34), категорія «підхід» $\epsilon$ усвідомленою орієнтацією фахівця на реалізацію у своїй професійній діяльності певної сукупності взаємопов'язаних цілей, цінностей, принципів, методів дослідницької, або практичної діяльності, відповідно до вимог освітньої парадигми. Н. К. Дюшеєва вбачає у методологічному підході стратегію, яка базується на основних положеннях відповідної теорії і визначає напрями пошуку стосовно предмета дослідження (2008, с. 117-118). Б. С. Гершунський вважає, що саме підхід до визначення компонентів навчально-виховних систем уособлює всі орієнтири реалізації відповідних доктрин освіти (останній може бути не єдиним і передбачати альтернативність використовуваних освітніх стратегій) (1998).

Погоджуємось із міркуванням Ю.А. Руденко про методологічний підхід як сукупність способів, методів, прийомів дослідження певного педагогічного явища, ставлення дослідника до організації, змісту, його реалізації та результативності експериментальної роботи $(2015$, с. 28$)$.

Зіставлення позицій вітчизняних і зарубіжних учених, таких як Ю. К. Бабанський, О. О. Бодальов, В. М. Галузинський, О. М. Гершунський, С. У. Гончаренко, Н. Б. Свтух, С. Г. Карпенчук, В.І. Лозова, І. П. Підласий, В. О. Сластьонін, М. М. Фіцула, дало змогу виокремити найчастіше пропоновані підходи до навчання та виховання: 1) диференційований; 2) діяльнісний; 3) індивідуальний; 4) комплексний; 5) особистісно-творчий; 6) особистісний; 7) системний; 8) структурний; 9) суб'єктоб'єктний; 10) суб'єкт-суб'єктний; 11) полісуб'єктний; 12) творчий.

Аналіз напрацювань А. П. Бєляєвої (1991), I. Б. Васильєва (2016) та ін. уможливлює розподіл наявних у науковому арсеналі підходів, залежно від об'єкта їхнього застосування, на три групи: 1) підходи до формування змісту освіти; 2) підходи до організації процесу освіти; 3) підходи до проведення наукових досліджень у сфері освіти. Тож, І. Б. Васильєв (2016) у контексті вивчення професійної підготовки педагогів характеризує такі методологічні підходи: 1) підходи до формування змісту підготовки - змістовно-акмеологічний, стандартизаційнопрофесіографічний, інформаційний, системно-компетентнісний, практикоорієнтований, комплексний; 2) підходи до організації процесу підготовки акмеологічний, структурно-логічний, технологічний, персоналізований, ресурсний, комплексно-діагностичний. 
Широкий спектр методологічних підходів дає змогу науковцям обирати будь-який підхід. Утім, як зауважує М. І. Олійник (2016), із позицій лише одного підходу важко зрозуміти сутність предмета дослідження, тож здебільшого вчені оперують сукупністю декількох підходів. Зокрема, у ракурсі осмислення проблем підготовки майбутніх вихователів Ю. А. Руденко застосовує системний і компетентнісний підходи (2015); I. О. Луценко вбачає потужний потенціал щодо процесу підготовки майбутніх вихователів в аксіологічному підході (2012); натомість I. І. Костікова поціновує системний, особистісний, діяльнісний, компетентнісний, інформаційний i синергетичний підходи як вирішальні щодо професійного навчання педагога (2008); М. І. Олійник, у ході вивчення підготовки майбутніх фахівців дошкільної освіти у країнах Східної Європи, пропонує послуговуватися компетентнісним і технологічним підходами (2016).

У результаті проведеного аналізу фахової літератури постають очевидними переваги підходу як явища наукової методології щодо вирішення низки теоретичних i практичних педагогічних проблем.

Робота у сфері освіти й особливо безпосередня педагогічна діяльність тісно пов'язана зі світоглядними засадами людини, навіть якщо це не є усвідомленим і не має очевидного вираження. Педагогічний процес здебільшого встановлює ціннісні орієнтації людини, тому дуже важливо в освітньому процесі керуватися таким світоглядним принципом, який орієнтує людей на творчу самореалізацію (Базалук та Юхименко, 2010, с. 93).

На нашу думку, методологічна функція рухового режиму в закладах дошкільної освіти набуває вияву в такій концептуально оформленій нами меті, як виховання дошкільника, який здатний відтворювати основні рухи й отримувати задоволення від самої рухової діяльності та виконання фізичних вправ, що у майбутньому уможливить розуміння ним впливу рухового режиму на власне здоров'я. Вважаємо, що формування такого досвіду в дитини сприяє реалізація вихователем оптимального рухового режиму в ЗДО, а його відтворення триває у процесі залучення дитини до різних форм рухової активності.

3 огляду на різноманітність підходів, напрацьованих у методології педагогічних досліджень, у процесі підготовки майбутніх вихователів до здійснення рухового режиму в ЗДО, їх застосування доцільно конкретизувати, як: системний, компетентнісний, діяльнісний підхід.

До провідних методологічних підходів належить системний, який постає методологічним підгрунтям будь-якої педагогічної студії. Філософські аспекти системного підходу розроблено в роботах філософів І. В. Блауберга, В. П. Кузьміна,
В. М. Садовського,
Е. Г. Юдіна, педагогів
О. А. Дубасенюк,
С. О. Сисоєвої,

Л. П. Сущенко та ін.

Ключове поняття означеного підходу - «система», розтлумачена вченими як «форма організації певної сукупності взаємопов'язаних елементів, їх властивостей i відношень між ними, об'єднуваних за спільною ознакою, призначенням; комплекс взаємодіючих елементів» (Васильєв, 2016, с. 73). Науковці вважають, що системою можна назвати лише такий комплекс вибіркових компонентів, у якому взаємодія i взаємовідношення будуть спрямовані на отримання сфокусованого корисного результату. Ю. А. Руденко системою номінує «упорядковані в єдине ціле безліч елементів, що перебувають у постійних взаємозв'язках і співвідношеннях один 3 одним і водночас у взаємодії з відповідним середовищем як цілісне явище і передбачає досягнення певного результату» (Руденко, 2015).

С. У. Гончаренко звертає увагу на системність як один із методологічних принципів дослідження. Учений стверджує, що «багатогранність сторін, елементів, відношень, внутрішніх і зовнішніх факторів функціонування і розвитку соціальнопедагогічного процесу визначає необхідність його системного вивчення» (Гончаренко, 2008 , с. 75$)$. Як зазначає А. П. Беляєва, «/.../системність може виступати в чотирьох 
взаємодоповнюваних аспектах: як єдність міждисциплінарного підходу у вигляді логічного синтезу; як поєднання теоретичного й емпіричного знання під час аналізу системних утворень (зміст освіти, навчання, формування, розвиток); як діалектичне взаємопроникнення модельно-пояснювального процесу та явищ педагогічної практики; як об'єднання інтеграційних i диференційованих процесів під час дослідження педагогічних систем професійної освіти» (Беляєва, 1999, с. 246).

Трактування науковцями «системного підходу» О. А. Дубасенюк розподілила на три групи: до першої належать бачення системного підходу як методу дослідження; другої - як напряму методології науки; третьої - як принципу пізнання практичної діяльності (Дубасенюк, 2015, с. 16).

На нашу думку, системний підхід закладає підвалини модернізації системи вищої освіти, а отже уможливлює забезпечення цілісності процесу формування професійної компетентності майбутніх вихователів за допомогою діяльності самого викладача, суб'єктивної свободи у виборі діяльності та ії компонентів, здійснення аналізу місця та функції усіх іiї складників і побудову іiї теоретичної моделі.

Застосування системного підходу до вирішення проблем підготовки майбутніх вихователів передбачає аналіз усіх факторів як множини взаємопов'язаних елементів, спрямованість діяльності суб'єкта на забезпечення оптимального функціонування педагогічних систем, до яких залучено об'єкти педагогічного впливу. Методологічну основу реалізації такого підходу визначають основні принципи: структурність, ієрархічність, цілісність, інваріантність, стійкість, керованість, адаптивність, взаємозв'язок системи із середовищем, взаємозв'язок зовнішніх і внутрішніх чинників на різних етапах підготовки.

Апробований у пропонованому дослідженні системний підхід щодо процесу підготовки майбутніх вихователів до здійснення рухового режиму в ЗДО спроектований на інтегративність фахових дисциплін («Вступ до спеціальності», «Вікова фізіологія та валеологія», «Психологія дитяча», «Педагогіка дошкільна», «Теорія та методика фізичного виховання та валеологічної освіти»), тобто на реалізацію принципу міжпредметних зв'язків. Комплексна професійна полікультурна підготовка майбутнього вихователя, зокрема до здійснення рухового режиму в ЗДО, передбачає наявність грунтовних міждисциплінарних знань. На наш погляд, застосування такого підходу дасть змогу сформувати цілісну, комплексну, поетапну, логічно вибудувану систему, що зорієнтована на результативність.

На сучасному етапі компетентнісний підхід проголошено одним зі стратегічних напрямів розвитку освіти в Україні. Тому вважаємо за необхідне взяти до уваги його засадничі положення під час побудови процесу підготовки майбутніх вихователів до здійснення рухового режиму в ЗДО. Компетентнісний підхід - предмет зацікавлення багатьох учених (О. Л. Богініч, А. М. Богуш, Н.В. Гавриш, О. І. Гура, О. А. Дубасенюк, А. П. Конох, Т.М. Котик, С. А. Литвиненко, С. В. Лісова, О. В. Овчарук, О. І. Пометун, Т. І. Поніманська, В. А. Семиченко), а також міжнародних спільнот (ЮНЕСКО, ЮНІСЕФ, Ради Європи, Організації європейського співробітництва та розвитку, Міжнародного департаменту стандартів), які опікуються проблемами розвитку освіти, організаційним і моніторинговим забезпеченням підготовки фахівців.

У колективній монографії за загальною редакцією О. В. Овчарук (Овчарук, 2004), а також у наукових працях О. І. Пометун, О. Я. Савченко та ін. розглянуто значення компетентнісного підходу в аспекті модернізації освіти й наголошено на тому, що перехід до компетентнісної освіти вимагає суттєвих змін у всіх ланках педагогічної системи, а значить - у ній самій як цілісності. Науковці переконують, що компетентності - це своєрідні комплекси знань, умінь і ставлень, яких набувають у ході навчання та які дають змогу людині розуміти, тобто ідентифікувати й оцінювати в різних контекстах проблеми, те, що вважається характерним для різних сфер діяльності.

Професійну компетентність здебільшого трактують як сукупність особистісних якостей, знань, умінь, що забезпечують високий рівень самоорганізації професійної 
діяльності, ऑii результатів, самопізнання та саморозвиток; як складне системне утворення, що постає складником професійної діяльності педагога й основою його майстерності та творчості. На переконання І. А. Зязюна, «складниками професіоналізму у будь-якій професії $є$ компетентність та озброєння системою вмінь» (Зязюн, 2000, с. 112).

Доречно звернути увагу, що Дж. Равен, розглядаючи компетентність із позицій психології, підкреслює, що вона складається із значної кількості компонентів, багато 3 яких відносно незалежні один від одного. Одні компоненти належать до когнітивної сфери, інші - до емоційної, які можуть значною мірою заміняти один одного як складники ефективної поведінки (Равен, 2002, с. 253-255).

В аспекті змісту підготовки майбутніх вихователів до здійснення рухового режиму в ЗДО компетентнісний підхід охоплює вміння оперувати своїми знаннями 3 організації та змісту різних форм фізичної культури, діяти професійно відповідно до окреслених закладами дошкільної освіти завдань у сфері фізичного виховання. Важливими $\epsilon$ також роль самостійної роботи студентів, виконання ними індивідуальних навчально-дослідних завдань, ефективне оперування активними методами навчання, а також розв'язування проблемних ситуацій і задач, створення методичного портфоліо студента.

Процес професійного становлення майбутніх вихователів, заснований на компетентнісному підході, передбачає проектування та моделювання особливостей здійснення рухового режиму в ЗДО, здатності творчо послугуватися набутими знаннями й досвідом на практиці. Саме компетентнісний підхід $є$ основою для обрання змісту професійної освіти відповідно до потреб майбутніх фахівців і водночас орієнтування його на комплексне вирішення оздоровчих, освітніх та виховних завдань. Залучення майбутніх вихователів до активного навчального процесу дасть їм змогу у майбутній педагогічній діяльності використовувати набуті знання й уміння для створення оптимального рухового режиму та підвищення рухової активності дітей.

У такому контексті вважаємо слушними твердження науковців О. П. Владиславлєва та Г. В. Бєлєнької. Приміром, за О. П. Владиславлєвим, «що вищим $є$ освітній рівень особистості, то активніше вона прагне до продовження освіти. При цьому освіта не тільки забезпечує і розвиває професійні та духовні потреби фахівця, а й стимулює розвиток нових» (Владиславлєв, 1978, с. 26). Г. В. Бєлєнька доводить, що рівні компетентності відзначаються ступенем позитивного впливу особистості на навколишню дійсність. На думку дослідниці, що вищий рівень професійної компетентності педагога, то глибший (суттєвий) i безпосередній, i опосередкований вплив чинить він на довкілля (через своїх вихованців, їхніх батьків, інших людей). Це пов'язано і зі збільшенням обсягу знань, досвіду, функцій професійної діяльності, і з розширенням повноважень особистості (Бєлєнька, 2012).

Основна ідея застосування компетентнісного підходу щодо підготовки майбутніх вихователів до здійснення рухового режиму в ЗДО полягає у визначенні статусу компетенцій як результату освіти, що охоплює всі аспекти діяльності - знаннєву, операційно-технологічну, ціннісно-мотиваційну тощо. Для з'ясування потенціалу компетентнісного підходу щодо порушеної в дослідженні проблеми розглянемо змістове наповнення поняття «компетенція».

Науковці компетенцією називають об'єктивну категорію, суспільно визнаний рівень знань, умінь, навичок, ставлень тощо у певній сфері діяльності людини як абстрактного носія (Овчарук, 2004, с. 93-102).

Зауважимо, що вчені розмежовують поняття «компетенція» і «компетентність». Зокрема, Г.В.Бєлєнька «компетенцію» тлумачить як наперед задану вимогу до освітньої підготовки (стандарт, опис повноважень, професіограму, дескриптор професії), потенційну можливість особистості; а «компетентність» - як професійну підготовленість і реалізовану здатність суб'єкта праці до виконання завдань і обов'язків повсякденної діяльності (ії структуру становлять мотиви, знання, уміння 
професійної діяльності, ставлення особистості і професійний досвід). 3 огляду на це професійну компетентність вихователя дошкільного навчального закладу дослідниця визначає як його здатність розв'язувати завдання професійної діяльності на основі фахових знань і умінь, що інтегровані з розвитком особистісних професійно значущих якостей, серед яких провідні - це любов до дітей, поєднана з вимогливістю, емпатія та комунікативність. Структурними компонентами останньої є мотиви, системні знання, фахові уміння та професійно значущі якості особистості, що внаслідок набуття особистістю професійного досвіду закріплюються та 3 часом посідають серед компонентів чільне місце. На думку автора, в умовах ступеневої підготовки в закладі вищої освіти професійна компетентність випускника зумовлена базовою та постає як здатність трансформувати особистісні та навчальні здобутки (знання, уміння, професійно значущі якості) у площину професійної діяльності (Бєлєнька, 2012).

Тому беззаперечним $є$ те, що поняття «компетенція» має вужче значення порівняно 3 поняттям «компетентність». Компетентність майбутнього вихователя охоплює такі сфери компетенції, як оздоровчо-профілактичну, діагностико-прогностичну, навчально-розвивальну, методичну, виховну, комунікативну, організаційнопедагогічну, контрольну, просвітницьку, самовдосконалення, кожна з яких вимагає від вихователя, крім професійних знань і вмінь, ще й наявності позитивних світоглядних настанов i розвитку певних особистісних професійно-значущих рис характеру (Бєлєнька, 2012).

У контексті дослідження, професійну компетентність майбутнього фахівця дошкільної освіти утворюють такі основні компоненти, як: теоретичні знання зі зміцнення здоров'я дітей, організації їхньої рухової активності протягом дня, організації фізкультурно-оздоровчої роботи в ЗДО, раціонального використання фізкультурного обладнання, організації активного відпочинку дітей; застосування умінь здійснення рухового режиму на практиці, що сприяє забезпеченню організації та здійсненню рухового режиму в ЗДО на високому рівні. За наявності перерахованих компонентів майбутній вихователь має змогу вільно, упевнено та професійно діяти, відповідно до вимог сьогодення. Загалом компетентнісний підхід постає критеріальним базисом для оцінювання ефективності підготовки студентів до здійснення рухового режиму в ЗДО, забезпечує можливості для розкриття структури професійної компетентності як результату фахової підготовки, виявлення найважливіших умов, що впливають на ії результативність, а також фактичні напрями іiї організації та здійснення.

Для забезпечення належної професійної підготовки студентів до здійснення рухового режиму в ЗДО на сучасному етапі апріорі доцільне врахування засадничих положень компетентнісного підходу.

Діяльнісний підхід визнано одним із провідних методологічних підходів педагогічної науки. Будь-який педагогічний напрям пов'язаний 3 організацією педагогічної діяльності, здійснюваної відповідно до таких методологічних принципів: розвитку предметності, історизму, активності (надситуативної як специфічної особливості людської психіки) тощо. Діяльнісний підхід передбачає, насамперед, організацію діяльності, іiі характеристику (специфіку розміщення, умови), побудову логічної структури діяльності (об'єкт, предмет, форми, засоби, методи, результат діяльності), структуру діяльності (стадії, етапи) та методику чи технологію виконання діяльності. Прикметно, що методологію розглядають як вчення про організацію діяльності, бо саме остання є її предметом (Руденко, 2015).

Основоположний принцип діяльнісного підходу - це принцип єдності свідомості та діяльності, який сформульований С. Л. Рубінштейном ще у 30-ті роки XX ст. Загальновизнану тезу «особистість у діяльності набуває і вияву, i формування», вважають стислим викладом його концепції. Розглядаючи діяльність і свідомість як органічне ціле, що створюють нерозривну єдність, учений називав діяльністю предметну, практичну діяльність (Рубінштейн, 1998, с. 99). На думку науковця, 
діяльність визначається своїм об'єктом через іiі внутрішні закономірності, зовнішні причини діють через внутрішні умови. Системою внутрішніх умов виступає особистість з ії складною багаторівневою структурою.

Теоретичний аналіз теорії діяльності слугує підставою для звернення до діяльнісного підходу як продуктивного щодо розроблення проблеми підготовки майбутніх вихователів до здійснення рухового режиму в ЗДО.

Діяльнісного підходу до професійно-педагогічної підготовки студентів дотримуються вчені Л. Г. Семушина, Н. Є. Колесник, Т. П. Танько, Ю. Г. Татур та ін. Прибічники такого підходу сприймають професійну підготовку як процес опанування знань, умінь і навичок, які уможливлюють виконання роботи у певній галузі професійної діяльності. Діяльнісний підхід дає змогу виокремити у програмах і навчальних посібниках практичні дії, способи поведінки, необхідні педагогу для вирішення реальних завдань педагогічної діяльності. На переконання Ю.Г. Татура, узагальненим результатом професійної освіти має стати готовність випускника до соціальної та професійної діяльності, оскільки лише шляхом власної активної діяльності людина здатна розвиватися (Татур, 2006, с. 47-48). Вважаємо раціональною побудову методичної підготовки майбутніх вихователів у межах діяльнісного підходу на грунті послідовного виконання типових професійних завдань.

Процес професійного становлення студентів, заснований на діяльнісному підході, дає змогу майбутнім вихователям моделювати руховий режим у наближених до професійних умовах. Вважаємо, що використання цього підходу стимулює майбутніх вихователів до професійної самоосвіти і самовиховання, інтенсифікує їхню самостійну роботу 3 опанування практичних умінь здійснювати руховий режим у ЗДО. Організація пізнавальної діяльності, базована на такому підході, дає змогу переглядати традиційні уявлення про освітній процес, забезпечуючи перетворення майбутніх вихователів з об'єкта впливу з боку викладача, в активний суб' єкт освітньої діяльності.

Висновки і перспективи подальших розвідок. Отже, за результатами аналізу науково-педагогічних досліджень зроблено висновок, що сучасні науковці оперують у процесі підготовки майбутніх вихователів широким комплексом освітніх підходів, серед яких - аксіологічний, діяльнісний, інформаційний, компетентнісний, особистісний, системний, синергетичний і технологічний.

Результатом підготовки майбутнього вихователя до здійснення рухового режиму в ЗДО на засадах системного, компетентнісного та діяльнісного підходів повинен бути фахівець, який не лише має теоретичні знання з організації й оптимізації рухового режиму, а й виявляє сформованість практичних умінь їхнього застосування.

Перспективи подальших наукових розвідок вбачаємо в системному аналізі ефективного поєднання теоретичних знань 3 організацією рухового режиму в ЗДО 3 практичними уміннями зі створення й застосування креативних форм рухової активності.

\section{СПИСОК ВИКОРИСТАНИХ ДЖЕРЕЛ}

Каган, М. (1991). Системный подход и гуманитарное знание. Лененград : Изд-во ЛГУ. С. $30-48$.

Дюшеева, Н. (2008). Методологические подходы к профессионально-личностному формированию будущего учителя. Пед. образование и наука. № 9. С.16-23.

Гершунский, Б. (1998). Философия образования для XXI века (В поисках практикоориентированных образовательных концепций). Москва: Совершенство. 608 с.

Руденко, Ю. (2015). Теоретико-методичні засади розвитку виразного мовлення майбутніх вихователів дошкільних навчальних закладів. Одеса: ФОП Бондаренко М. О. $460 \mathrm{c}$.

Васильев, И. (2016). Теоретические и методические основы подготовки педагогов профессионального обучения. Доктор педагогических наук. Национальная академия педагогических наук Украины, Институт педагогического образования и образования взрослых. 
Беляева, А. (1991). Дидактические принципы профессиональной подготовки в профтехучилищах. Москва : Высш. шк. 208 с.

Олійник, М. (2016). Теоретико-методичні засади підготовки майбутніх фахівців дошкільної освіти в краӥнах Східної Європи. Доктор педагогічних наук. Тернопільський національний педагогічний університет ім. Володимира Гнатюка.

Луценко, І. (2012). Аксіологічний підхід до підготовки майбутніх вихователів до формування комунікативно-мовленнєвої діяльності дітей дошкільного віку. Вісн. ін-mу розвитку дитини. Серія: Філософія. Педагогіка. Психологія : зб. наук. пр. Нац. пед. унт ім. М. П. Драгоманова. Київ : Вид-во НПУ ім. М. П. Драгоманова. Вип. 22. С. 92-99.

Базалук, О. та Юхименко, Н. (2010). Філософія освіти. Київ. 164 с.

Костікова, I. (2008). Сучасні методологічні підходи професійної підготовки вчителя засобами інформаційно-комунікаційних технологій. Педагогіка, психологія та медико-біологічні проблеми фізичного виховання і спорту. № 8. С. 79-83.

Гончаренко, С. (2008). Педагогічні дослідження: методологічні поради молодим науковцям. Київ ; Вінниця : ДОВ «Вінниця». 278 с.

Беляева, А. (1999). Методология и теория профессиональной педагогики. СанктПетербург. Ин-т профтехобразования: РАО. 480 с.

Дубасенюк, О. [ред.], (2015). Професійна педагогічна освіта: системні дослідження. Житомир : Вид-во ЖДУ ім. І. Франка. 308 с.

Овчарук, В. [ред.], (2004). Компетентнісний підхід у сучасній освіті: світовий досвід та украӥнські перспективи. Київ : К.І.С. 112 с. (Бібліотека з освітньої політики).

Зязюн, І. (2000). Педагогіка добра: ідеали і реалії. Київ : МАУП. 312 с.

Равен, Д. (2002). Компетентность в современном обществе: выявление, развитие и реализация. Москва : Когито-Центр. 396 с.

Владиславлев, О. (1978). Непрерывное образование. Проблемы и перспективы. Москва : Мол. гвардия. $176 \mathrm{c.}$

Бєлєнька, Г. (2012). Формування професійної компетентності майбутніх вихователів дітей дошкільного віку в умовах університетської освіти. Наук. зап. Ніжин. держ. ун-ту ім. Миколи Гоголя. Серія: Психолого-педагогічні науки. № 4. C. 114-119. [online]. URL: http://nbuv.gov.ua/UJRN/Nzspp_2012_4_25. [Дата звернення 13.10.2019 p.].

Рубинштейн, С. (1998). Основы общей психологии. СПб.: Питер Ком. 688 с.

Татур, Ю. (2006) Высшее образование: методология $u$ опьт проектирования. М.: Университет. кн. ; Логос. 256 с.

\section{REFERENCES}

Kagan. M. (1991). Sistemnyi podkhod i gumanitarnoye znaniye [Systematic Approach and Knowledge of Humanities]. Lenengrad : Izd-vo LGU. s. 30-48. (in Russian)

Dyusheyeva. N. (2008). Metodologicheskiye podkhody k professionalno-lichnostnomu formirovaniyu budushchego uchitelya [Methodological Approaches to the Professional and Personal Formation of the Future Teacher]. Ped. obrazovaniye i nauka. No 9. S.16-23. (in Ukrainian)

Gershunskiy. B. (1998). Filosofiya obrazovaniya dlya XXI veka (V poiskakh praktikooriyentirovannykh obrazovatelnykh kontseptsiy) [Philosophy of Education for the 21st Century (In Search of Practice-oriented Educational Concepts)]. Moskva : Sovershenstvo. 608 s. (in Ukrainian)

Rudenko, Yu. (2015). Teoretyko-metodychni zasady rozvytku vyraznoho movlennia maibutnikh vykhovateliv doshkilnykh navchalnykh zakladiv [Theoretical and Methodological Foundations of Expressive Speech Development of Future Preschool Teachers]. Odesa: FOP Bondarenko M. O. 460 s. (in Ukrainian)

Vasilyev. I. (2016). Teoreticheskiye i metodicheskiye osnovy podgotovki pedagogov professionalnogo obucheniya [Theoretical and Methodological Foundations of Teachers' Training in the Field of Professional Education]. Doktor pedagogicheskikh nauk. 
Natsionalnaya akademiya pedagogicheskikh nauk Ukrainy. Institut pedagogicheskogo obrazovaniya i obrazovaniya vzroslykh. (in Ukrainian)

Belyayeva. A. (1991). Didakticheskiye printsipy professionalnoy podgotovki $v$ proftekhuchilishchakh [Didactic Principles of Professional Training in Vocational Schools]. Moskva : Vyssh. shk. 208 s. (in Ukrainian)

Oliinyk, M. (2016). Teoretyko-metodychni zasady pidhotovky maibutnikh fakhivtsiv doshkilnoi osvity v krainakh Skhidnoi Yevropy [Theoretical and Methodological Bases of Education of Future Specialists in the Field of Preschool Education in the Countries of Eastern Europe]. Doktor pedahohichnykh nauk. Ternopilskyi natsionalnyi pedahohichnyi universytet im. Volodymyra Hnatiuka. (in Ukrainian)

Lutsenko, I. (2012). Aksiolohichnyi pidkhid do pidhotovky maibutnikh vykhovateliv do formuvannia komunikatyvno-movlennievoi diialnosti ditei doshkilnoho viku [Axiological Approach to Training of Future Caregivers for the Formation of Communicative Activity among Preschool Children]. Visn. in-tu rozvytku dytyny. Seriia: Filosofiia. Pedahohika. Psykholohiia : zb. nauk. pr. Nats. ped. un-t im. M. P. Drahomanova. Kyiv : Vyd-vo NPU im. M. P. Drahomanova. Vyp. 22. S. 92-99. (in Ukrainian)

Bazaluk, O. \& Yukhymenko N. (2010) Filosofiia osvity [Philosophy of Education]. Kyiv. 164 s. (in Ukrainian)

Kostikova, I. (2008). Suchasni metodolohichni pidkhody profesiinoi pidhotovky vchytelia zasobamy informatsiino-komunikatsiinykh tekhnolohii [Modern Methodological Approaches to Teacher Professional Training by Means of Information and Communication Technologies]. Pedahohika, psykholohiia ta medyko-biolohichni problemy fizychnoho vykhovannia i sportu. No 8. S. 79-83. (in Ukrainian)

Honcharenko, S. (2008). Pedahohichni doslidzhennia: metodolohichni porady molodym naukovtsiam [Pedagogical Research: Methodological Advice for Young Scientists]. Kyiv ; Vinnytsia : DOV "Vinnytsia". 278 s. (in Ukrainian)

Belyayeva. A. (1999). Metodologiya i teoriya professionalnoy pedagogiki [Methodology and Theory of Professional Pedagogy]. Sankt-Peterburg In-t proftekhobrazovaniya: RAO. 480 s. (in Ukrainian)

Dubaseniuk, O. [red.], (2015). Profesiina pedahohichna osvita: systemni doslidzhennia [Professional Pedagogical Education: Systematic Studies]. Zhytomyr : Vyd-vo ZhDU im. I. Franka. 308 s. (in Ukrainian)

Ovcharuk, O. [red.], (2004). Kompetentnisnyi pidkhid u suchasnii osviti: svitovyi dosvid ta ukrainski perspektyvy [Competence Approach in Modern Education: World Experience and Ukrainian Perspectives]. Kyiv : K.I.S. 112 s. (Biblioteka z osvitnoi polityky). (in Ukrainian)

Ziaziun, I. (2000). Pedahohika dobra: idealy i realii [Pedagogy of Kindness: Ideals and Realities]. Kyiv : MAUP. 312 s. (in Ukrainian)

Raven. D. (2002). Kompetentnost v sovremennom obshchestve: vyyavleniye. razvitiye $i$ realizatsiya [Competence in Modern Society: Identification, Development and Implementation]. Moskva : Kogito-Tsentr. 396 s. (in Russian)

Vladislavlev. O. (1978). Nepreryvnoye obrazovaniye. Problemy $i$ perspektivy [Continuous Education. Problems and Perspectives]. Moskva : Mol. gvardiya. $176 \mathrm{~s}$.

Bielienka, H. (2012). Formuvannia profesiinoi kompetentnosti maibutnikh vykhovateliv ditei doshkilnoho viku v umovakh universytetskoi osvity [Formation of Professional Competence of Future Preschool Teachers in the Context of University Education]. Nauk. zap. Nizhyn. derzh. un-tu im. Mykoly Hoholia. Seriia: Psykholoho-pedahohichni nauky. No 4. S. 114-119. [online]. URL: http://nbuv.gov.ua/UJRN/Nzspp_2012_4_25. [Data zvernennia 13.10.2019 r.]. (in Ukrainian)

Rubinshteyn. S. (1998). Osnovy obshchey psikhologii [Fundations of General Psychology]. Sankt-Peterburg: Piter Kom. 688 s. (in Russian) 
Tatur. Yu. (2006) Vyssheye obrazovaniye: metodologiya $i$ opyt proyektirovaniya [University Education: Methodology and Design Experience]. Moskva: Universitet. kn. ; Logos. 256 s. (in Russian)

\title{
BASIC APPROACHES TO THE PROCESS OF PREPARING OF FUTURE PRESCHOOL TEACHERS TO THE IMPLEMENTATION OF MOTOR MODE IN PRESCHOOL INSTITUTIONS
}

\author{
Oleksii Yurchuk \\ Candidate of Pedagogical Sciences, \\ Senior Lecturer at the Department of Pedagogy \\ and Psychology (Preschool and Correctional) \\ named after Professor T.Ponimanska, \\ Rivne State University for the Humanities, \\ Rivne, Ukraine \\ ORCID: 0000-0002-4764-1783 \\ e-mail:abstractio@ukr.net
}

\begin{abstract}
The article deals with the peculiarities of the future preschool teachers' preparation process for the implementation of the motor mode in the preschools. The views of Ukrainian and foreign scholars on various theoretical pedagogical approaches are analyzed: systemic, competence and activity. The importance of modern methodological approaches as decisive for the scientific substantiation of future preschool teachers' effective vocational training and the formation of professional knowledge regarding the implementation of the motor mode in the preschools has been revealed. Methodological approaches are substantiated and their possibilities in organizing the process of the future preschool teachers' preparing for the implementation of the motor mode in the preschools have been revealed.

It was found that the use of a systemic approach makes it possible to ensure the integrity of the process of forming the future preschool teachers' professional competence through the activity of the teacher, subjective freedom in the choice of activities and its components, to analyze the places and functions of all its constituents and to build its theoretical model.

Within the competence approach, the status of competences as a result of education is traced, covering all aspects of activity - knowledge, operational-technological, valuemotivational, etc.

The effectiveness of the activity approach to the process of the future preschool teachers' professional formation in the conditions close to the professional ones has been determined. Attention was drawn to the fact that the organization of cognitive activity based on this approach makes it possible to review the traditional ideas about the educational process, ensuring the transformation of the future preschool teachers from the object of influence of the teacher into an active subject of educational activity.
\end{abstract}

Keywords: future preschool teachers, motor mode, theoretical approaches, systemic approach, competence approach, activity approach.

Стаття надійшла до редакиії 10.10.2019 p. 